\title{
PENGARUH MODEL DISCOVERY LEARNING BERBANTUAN MEDIA PhET TERHADAP HASIL BELAJAR FISIKA PESERTA DIDIK KELAS XI SMAN 1 KEDIRI TAHUN AJARAN 2017/2018
}

\author{
Hamidah Lidiana*, Gunawan, Muhammad Taufik \\ Program Studi Pendidikan Fisika, Universitas Mataram \\ *Email: hamidahlidiana575@gmail.com
}

\begin{abstract}
This research aimed to figure out the effect of discovery learning using PhET to the learning outcome in physics of the second-grade students in SMAN 1 Kediri Academic Year 2017/2018. This research was conducted as the result of experiment using non-equivalent control group design. The population of this research was the whole second-grade students in SMAN 1 Kediri. To limit the sample, surfeited sampling was applied consisting the students in class XI MS I as the experiment class and class MS II as the control class. Research instrument used was the multiplechoice test after the tests of validity, reliability, discrimination power, and difficulty level have been done. The increasing of the learning outcome was defined from the result of $N$-gain test per subchapter. The result of this research showed that the learning outcome of the students has increased to both classes. This proved that discovery learning method using PhET has succeeded in increasing the students' learning outcome for Physics.
\end{abstract}

Keywords: Discovery Learning method, PhET, Learning Outcome.

\section{PENDAHULUAN}

Mata pelajaran fisika merupakan salah satu cabang dari IPA dan merupakan ilmu pengetahuan yang mempelajari fenomena alam melalui berbagai proses ilmiah. Fisika pada jenjang SMA memiliki beberapa tujuan, diantaranya adalah agar peserta didik memiliki kemampuan: (1) mengembangkan kemampuan bernalar dalam berfikir analisis induktif dan deduktif dengan menggunakan konsep dan prinsip fisika untuk menjelaskan berbagai peristiwa alam dan penyelesaian masalah baik secara kualitatif maupun kuantitatif; (2) menguasai konsep dan prinsip fisika serta mempunyai keterampilan mengembangkan ilmu pengetahuan dan teknologi (Pebriyanti, 2015).

Keberhasilan tujuan pembelajaran fisika pada jenjang SMA sangat diharapkan terutama ditentukan oleh pembelajaran yang dialami peserta didik dengan ketepatan model pembelajaran yang digunakan guru ketika kegiatan mengajar fisika. Penggunaan suatu model pembelajaran akan efektif apabila penerapan yang dilakukan sesuai dengan tujuan pembelajaran. Tujuan belajar menurut Ilahi (2012) adalah hal yang paling realistis untuk mengasah kemampuan otak agar tetap berjalan optimal dan mampu diterapkan dalam konteks realitas kehidupan.

Berdasarkan hasil observasi peneliti melalui wawancara di SMAN 1 Kediri, terdapat beberapa permasalahan dalam pembelajaran fisika, yakni peserta didik beranggapan bahwa fisika itu sulit, banyak rumus, membosankan dan menakutkan, selaian itu peserta didik malas bertanya serta kurang kreatif jika tidak mengerti materi yang diajarkan, sehingga mengakibatkan hasil belajar peserta didik rendah. Hasil belajar adalah perilakuperilaku kejiwaan yang akan diubah dalam proses pendidikan. Hasil belajar terbagi menjadi tiga, yaitu: kognitif, afektif dan psikomotorik (Purwanto, 2013). Sebagai gambaran, berikut ini disajikan nilai ratarata UAS (Ujian Akhir Semester) fisika 
peserta didik kelas X MS (Minat Sains)

SMAN 1 Kediri tahun ajaran 2016/2017.

Berdasarkan Tabel 1.1 dapat di lihat bahwa hasil belajar fisika peserta didik belum mencapai KKM (Kreteria Ketuntasan
Maksimum) yang ditetapkan yaitu 75 . Adapun nilai rata-rata UAS fisika peserta didik semester genap pada tahun ajaran 2016/2017 dapat dilihat pada Tabel 1 berikut.

Tabel 1. Nilai Ulangan Akhir Semester (UAS)

\begin{tabular}{llll}
\hline No. & Kelas & Jumlah peserta didik & Nilai rata-rata \\
\hline 1 & X MS I & 22 & 66,45 \\
2 & X MS II & 23 & 66,56 \\
\hline \multicolumn{5}{r}{} \\
\end{tabular}

Berdasarkan permasalahan dari hasil observasi yang telah dijabarkan, guru sebagai tenaga pendidik perlu menciptakan suatu inovasi yang kreatif dalam pembelajaran fisika. Peserta didik bebas dalam mengeluarkan pendapatnya dan menemukan sendiri permasalahan yang dihadapinya. Sehingga diperlukan suatu model pembelajaran yang tepat seperti model discovery learning berbantuan media PhET. Media simulasi PhET yang disediakan sangat interaktif dan mengajak peserta didik untuk belajar dengan cara mengeksplorasi secara langsung. Software PhET ini memuat suatu animasi fisika yang abstrak atau tidak dapat dilihat oleh mata terbuka, seperti : alat dan bahan yang digunakan pada materi elastisitas. Untuk eksplorasi secara kuantitatif, software PhET ini memiliki alat-alat ukur di dalamnya seperti penggaris, stopwatch, voltmeter dan termometer (Sugiarti, 2015).

Discovery learning merupakan suatu model pembelajaran yang melibatkan secara maksimal seluruh kemampuan peserta didik untuk mencari dan menemukan sesuatu (benda, manusia, atau peristiwa) secara sistematis, kritis, logis, analitis sehingga peserta didik dapat merumuskan sendiri penemuanya dengan penuh percaya diri (Muryani, 2015). Ilahi (2012) menyatakan bahwa pembelajaran discovery learning adalah usaha untuk memperoleh pengertian dan pemahaman yang lebih daripada inquiry. Model discovery learning akan menciptakan suasana belajar yang lebih aktif. Peserta didik tidak hanya menerima penjelasan dari guru, melainkan juga memecahkan masalah dengan mencari sendiri pengetahuannya melalui sumber-sumber yang ada tetapi tetap dengan bimbingan guru, kemudian Kelebihan dari simulasi PhET yaitu menekankan hubungan antara fenomena kehidupan nyata dengan ilmu yang mendasari (Jauhari, 2016). Sehingga dari kelebihan tersebut mampu meningkatkan hasil belajar peserta didik.

Penelitian ini didukung oleh penelitian yang dilakukan oleh Sugiarti (2015) menyatakan bahwa penggunaan simulasi $\mathrm{PhET}$ dalam pembelajaran dapat membangun konsep dan keterampilan proses sains peserta didik. Selain itu penggunaan media virtual seperti laboratorium virtual juga dapat meningkatkan hasil belajar peserta didik. Gunawan et al. (2017) mengungkapkan bahwa penggunaan laboratorium virtual dalam pembelajaran konsep listrik dapat meningkatkan kemampuan penyelesaian masalah. Penelitian terkait dengan model discovery learning antara lain dilakukan oleh Mubarok (2014) yang menyatakan bahwa model discovery learning berpengaruh positif terhadap hasil belajar peserta didik. Belum adanya penggunaan model discovery learning yang 
digabungkan dengan media PhET, sehingga peneliti merasa tertarik untuk melakukan penelitian yang berjudul "Pengaruh Model Discovery Learning Berbantuan Media PhET Terhadap Kreativitas dan Hasil Belajar Fisika Peserta Didik Kelas XI SMAN 1 Kediri Tahun Ajaran 2017/2018”.

\section{METODE PENELITIAN}

Penelitian kuasi eksperimen ini menggunakan non-equivalent control group design. Populasi yang diteliti adalah seluruh peserta didik kelas XI MS SMAN 1 Kediri yang terdiri dari 2 kelas. Kelas MS.1 sebagai eksperimen dan MS.2 sebagai kelas kontrol. Penelitian ini dilaksanakan di SMAN 1 Kediri kelas XI pada bulan Agustus sampai September 2017. Teknik sampel yang digunakan dalam penelitian ini yaitu sampling jenuh.

Dalam penelitian terdapat variabel terikat yaitu hasil belajar fisika, variabel bebas yaitu model discovery learning berbantuan media PhET dan variabel kontrol yaitu materi, instrumen, penilaian, waktu, dan jam pelajaran. Pada kelas eksperimen diberi perlakuan dengan model discovery learning berbantuan media PhET. Sedangkan kelas kontrol diberikan perlakuan berupa model pembelajaran langsung tanpa berbantuan media PhET.

Instrumen tes digunakan untuk mengukur hasil belajar fisika peserta didik berbentuk pilihan ganda yang berjumlah 32 butir soal yang sudah disiapkan di uji pada 20 peserta didik kelas XII kemudian dianalisis untuk mengetahui tingkat kelayakannya yakni dengan menghitung validitas, reliabilitas, analisis tingkat kesukaran dan analisis daya pembeda.

Prasyarat analisis uji hipotesis, yaitu uji normalitas dengan uji Chi Kuadrat dan uji homogenitas dengan uji F. Analisis uji hipotesis melalui uji t berbantuan program Microsoft Excel 2010.

\section{HASIL DAN PEMBAHASAN}

Tes hasil belajar yang diujikan pada penelitian ini terdiri dari 27 soal pilihan ganda. Sebelum mendapatkan 27 soal, peneliti melakukan uji validitas soal pada kelas XII IPA 1 dengan membuat 32 soal. Pada hasil uji coba instrumen terdapat 25 soal yang diterima, 2 soal yang direvisi dan 5 soal ditolak. Berdasarkan hasil uji validitas tersebut, terdapat 7 soal yang tidak valid. Dari 7 soal yang tidak valid 2 soal yang direvisi. Sehingga peneliti menyimpulkan untuk mengambil 27 soal untuk digunakan saat tes awal dan tes akhir. Hasil belajar pada penelitian ini diukur berdasarkan hasil belajar peserta didik pada ranah kognitif, yaitu $\mathrm{C} 1, \mathrm{C} 2, \mathrm{C} 3, \mathrm{C} 4, \mathrm{C} 5$, dan C6.

Data yang diperoleh dalam penelitian ini adalah data yang terkumpul dari hasil tes awal dan tes akhir. Tes awal bertujuan untuk mengetahui kemampuan awal peserta didik kelas eksperimen dan kontrol. Tes akhir diberikan setelah diberikan perlakuan, dengan tujuan untuk mengetahui kemampuan akhir kedua kelas. Data hasil belajar peserta didik kelas eksperimen dan kelas kontrol disajikan pada Tabel 2.

Tabel 2. Nilai Hasil Belajar

\begin{tabular}{llccc}
\hline & \multicolumn{2}{l}{ Kelas Eksperimen } & \multicolumn{2}{c}{ Kelas Kontrol } \\
\cline { 2 - 5 } & Tes Awal & Tes Akhir & Tes Awal & Tes Akhir \\
\hline Skor maksimum & 48 & 93 & 52 & 89 \\
Skor minimum & 19 & 63 & 15 & 37 \\
Rata-rata & 32 & 76 & 33 & 67 \\
N & 19 & 19 & 20 & 20 \\
\hline
\end{tabular}


Berdasarkan Tabel 2 terlihat bahwa kemampuan akhir hasil belajar berbeda dengan kemampuan awalnya. Kelas eksperimen maupun kelas kontrol mengalami peningkatan, namun peningkatan kelas eksperimen lebih baik daripada kelas kontrol. Hal ini dikarenakan model discovery learning yang digunakan melibatkan secara langsung kemampuan peserta didik untuk mencari dan menemukan sendiri permasalahan secara sistematis, kritis, logis, analitis, sehingga peserta didik dapat menemukan sendiri jawaban dari permasalahn yang ditemukan dengan rasa puas dan percaya diri dan mengakibatkan peningkatan pada hasil pembelajaran pada kelas eksperimen, serta ini juga sejalan dengan penelitian yang dilkukan Hayati, et al (2017) menyatakan bahwa hasil belajar menggunakan model pembelajaran inquiri dengan menggunakan media simulasi PhET lebih tinggi dari hasil belajar peserta didik yang menggunakan model pembelajaran konvensional. Nilai tertinggi tes awal hasil belajar peserta didik di kelas eksperimen diperoleh 48 dan nilai terendah 19, sedangkan nilai tertinggi hasil belajar peserta didik di kelas kontrol diperoleh 52 dan nilai terendah 15 . Tes akhir hasil belajar peserta didik di kelas eksperimen diperoleh niai tertinggi 93 dan nilai terendah 63 , sedangkan untuk kelas kontrol diperoleh nilai tertinggi 89 dan nilai terendah 37. Rata-rata nilai tes awal pada kelas ekperimen adalah 32,37 dan kelas kontrol adalah 33,30. Rata-rata nilai tes akhir hasil belajar peserta didik pada kelas eksperimen adalah 76,16 dan kelas kontrol adalah 67,00 Terlihat bahwa peningkatan kelas eksperimen lebih tinggi dari kelas kontrol, baik nilai tertinggi, nilai terendah dan rata-rata yang diperoleh. Hasil tes awal dan tes akhir digunakan untuk mengetahui homogenitas, normalitas dan uji hipotesis.

Perhitungan homogenitas dilakukan dengan menganalisis masing- masing kelas yakni menganalisis homogenitas kelas kontrol dengan kelas eksperimen. Uji homogenitas data untuk tes awal yang telah dilakukan dengan taraf signifikan 0,05 didapat nilai $F_{\text {hitung }}$ sebesar 1,64 sedangkan nilai $F_{\text {tabel }} 2,19$. Tes akhir kedua kelas homogen, karena $F_{\text {hitung }}<\mathrm{F}_{\text {tabel. }}$ Tes akhir didapatkan nilai $F_{\text {hitung }}$ sebesar 1,23 sedangkan nilai $\mathrm{F}_{\text {tabel }} 2,19$ dengan taraf signifikan 0,05 . Tes akhir kedua kelas homogen, karena $F_{\text {hitung }}<F_{\text {tabel }}$.

Uji normalitas dilakukan untuk mengetahui data terdistribusi normal atau tidak. Uji normalitas dilakukan dengan rumus Chi-Kuadrat $\left(X^{2}\right)$.

Dari perhitungan uji normalitas data tes awal dan tes akhir dilakukan pada masing-masing kelas. Berdasarkan perhitungan yang telah dlakukan didapatkan hasil bahwa data berdistribusi normal pada tes awal dan tes akhir untuk kelas eksperimen maupun kelas kontrol. Tes awal didapatkan nilai $\chi_{\text {hitung }}^{2}$ sebesar 3,68 untuk kelas eksperimen dan 5,25 untuk kelas kontrol. Nilai $\chi^{2}$ tabel dengan taraf signifikan 0,05 untuk kedua kelas sebesar 11,07. Data tes awal untuk kedua kelas berdistribusi normal, karena $\chi_{\text {hitung }}^{2}$ $\chi_{\text {tabel }}^{2}$. Nilai $\chi_{\text {hitung }}^{2}$ tes akhir untuk kelas eksperimen sebesar 3,47 dan untuk kelas kontrol sebesar 1,44 . Nilai $\chi_{\text {tabel }}^{2}$ dengan taraf signifikan 0,05 untuk kedua kelas adalah 11,07 , sehingga data tes akhir kedua kelas terdistribusi normal.

Uji hipotesis dilakukan dengan menganalisis data hasil tes akhir kelas eksperimen dan kelas kontrol. Uji hipotesis yang digunakan adalah uji-t polled varians karena jumlah sampel pada kelas ekperimen dan kelas kontrol tidak sama. Dari hasil perhitungan uji hipotesis dilakukan dengan menganalisis data hasil tes akhir kelas eksperimen yang diberikan perlakuan berupa pengaruh model discovery learning berbantuan media PhET dan kelas kontrol 
yang di berikan perlakuan berupa model pembelajaran langsung tanpa berbantuan media PhET. Uji hipotesis yang digunakan adalah uji-t polled varians karena jumlah sampel pada kelas ekperimen dan kelas kontrol tidak sama. Hasil uji statistik yang dilakukan didapatkan nilai $t_{\text {hitung }}$ sebesar 2,234. Nilai thitung tersebut lebih besar

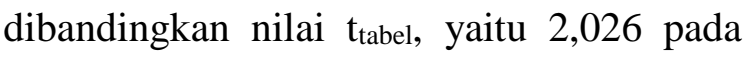
taraf signifikan 0,05. Sehingga disimpulkan bahwa Ho ditolak, yaitu tidak ada pengaruh model discovery learning berbantuan media PhET terhadap hasil belajar fisika peserta didik.

Analisis hasil belajar peserta didik tidak hanya pada nilai akhirnya saja, tetapi dilakukan analisis per sub materi yang diajarkan. Materi yang diajarkan yaitu Elastisitas dan Hukum Hooke. Materi tersebut memiliki 4 sub bab diantaranya sifat elastis bahan, tegangan dan regangan, Hukum Hooke, dan rangkaian seri-paralel.

Berdasarkan analisis dapat diketahui bahwa perolehan Persentase N-gain tertinggi terdapat pada kelas eksperimen. Kelas eksperimen memiliki nilai $\mathrm{N}$-gain dengan katagori tinggi terdapat pada materi sifat elastis bahan, sedangkan pada materi lain berada pada katagori sedang, sedangkan pada kelas kontrol nilai $\mathrm{N}$-gain pada semua materi berada pada katagori sedang.yaitu pada sub materi sifat elastis bahan sebesar $78 \%$ dan terendah sebesar $58 \%$ pada materi rangkaian seri-paralel. Sedangkan untuk kelas kontrol Persentase $\mathrm{N}$-gain tertinggi pada sub-materi sifat elastis bahan sebesar 59\% dan terendah $44 \%$ pada sub-materi tegangan dan regangan. Penjabaran tersebut dikarenakan beberapa soal pada materi Elastisitas dan Hukum Hooke dengan kategori sedang dan mudah dengan daya beda yang baik dan cukup. Pernyataan ini sesuai dengan penelitian yang dilakukan oleh Sugiana, et al (2016) menyatakan bahwa model pembelajaran generatif berbantuan media laboratorium virtual pada materi Momentum dan Impuls dapat meningkatkan penguasaan konsep peserta didik. Selain itu Gunawan et al. (2017) juga mengungkapkan penggunaan model project based learning berbantuan media virtual dapat meningkatkan kreativitas peserta didik. Peningkatannya dapat juga dilihat pada Gambar 1 berikut.

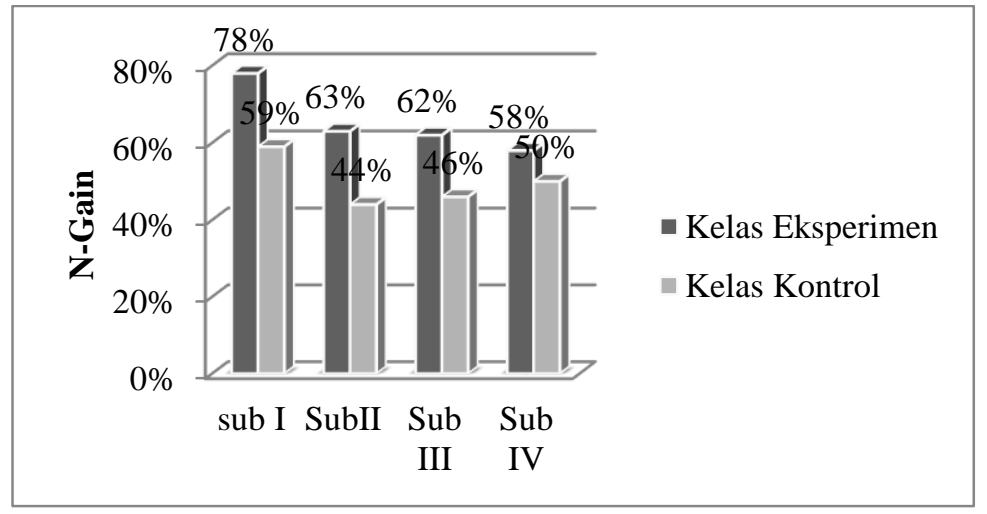

Gambar 1. Hasil Uji N-gain Pada Setiap Sub Materi

Berdasarkan Gambar 1 hasil belajar tiap sub bab pada kelas eksperimen dan kelas kontrol meningkat. Secara keseluruhan peningkatan hasil belajar kelas eksperimen lebih tinggi daripada kelas kontrol. Dari segi aspek kognitif dapat dilihat peningkatan pada kelas eksperimen dan kontrol dari tes awal hingga tes akhir seperti pada Tabel 3 berikut. 
Tabel 3. Data Peningkatan Aspek Kognitif

\begin{tabular}{clcccccc}
\hline \multicolumn{2}{c}{ Aspek Kognitif } & $\begin{array}{c}\text { Hafalan } \\
(\mathrm{C} 1)\end{array}$ & $\begin{array}{c}\text { Pemahaman } \\
(\mathrm{C} 2)\end{array}$ & $\begin{array}{c}\text { Penerapan } \\
(\mathrm{C} 3)\end{array}$ & $\begin{array}{c}\text { Analisis } \\
(\mathrm{C} 4)\end{array}$ & $\begin{array}{c}\text { Sintesis } \\
(\mathrm{C} 5)\end{array}$ & $\begin{array}{c}\text { Evaluasi } \\
(\mathrm{C} 6)\end{array}$ \\
\hline \multirow{2}{*}{ Tes awal } & Eksperimen & $58 \%$ & $37 \%$ & $29 \%$ & $29 \%$ & $32 \%$ & $32 \%$ \\
\cline { 2 - 8 } & Kontrol & $60 \%$ & $36 \%$ & $32 \%$ & $31 \%$ & $26 \%$ & $33 \%$ \\
\hline \multirow{2}{*}{ Tes akhir } & Eksperimen & $89 \%$ & $81 \%$ & $71 \%$ & $72 \%$ & $74 \%$ & $81 \%$ \\
\cline { 2 - 8 } & Kontrol & $87 \%$ & $72 \%$ & $65 \%$ & $61 \%$ & $61 \%$ & $67 \%$ \\
\hline
\end{tabular}

Tabel 3 dapat dilihat peningkatan aspek kognitif hasil belajar dari nilai tes awal hingga tes akhir kedua kelas. Kriteria peningkatan pada kelas eksperimen lebih baik daripada kelas kontrol hal ini dikarenakan karna pada kelas eksperimen diberikan perlakuan berupa model discovery learning berbantuan media $\mathrm{PhET}$, yang mana model yang digunakan ini berpusat pada peserta didik sehingga mengakibatkan peningkatan pada ranah sintesis (C5) dan hafalan (C1).

Temuan dalam penelitian ini memperkuat beberapa penelitian sebelumnya diantaranya penelitian yang dilakukan Supradnyana, et al (2016) menyatakan bahwa terdapat perbedaan yang signifikan hasil belajar antara peserta didik yang diajaarkan menggunakan model pembelajaran Discovery Learning berbantuan media audio visual lebih tinggi dari peserta didik yang dibelajarkan menggunakan model pembelajaran konvensional, dan dalam penelitian lain keterampilan berpikir kritis Mahasiswa memberikan tanggapan positif ketika mengunakan model pembelajaran berbasis masalah berbantuan simulasi komputer pada materi listrik statis, dimana dosen dan mahasiswa juga memberikan tanggapan yang positif Herayanti dan Habib (2015) serta Nurhayati, et al (2014) menyatakan hasil belajar peserta didik yang diajarkan dengan metode demonstrasi berbantu media animasi Software PhET lebih baik dari pada hasil belajar peserta didik dengan menggunakan metode konvensional.

\section{PENUTUP}

Berdasarkan hasil penelitian dan pembahasan, dapat disimpulkan bahwa terdapat perbedaan hasil belajar fisika antara peserta didik kelas eksperimen dan kelas kontrol. Hasil belajar fisika kelas eksperimen yang diberikan perlakuan dengan model discovery learning lebih tinggi dari hasil belajar fisika kelas kontrol yang diberi perlakuan berupa model pembelajaran langsung. Pembelajaran dengan menggunakan model discovery learning berbantuan media PhET berpengaruh positif terhadap hasil belajar fisika kelas XI SMAN 1 Kediri. Model discovery learning berbantuan media PhET mampu meningkatkan hasil belajar peserta didik pada ranah kognitif $\mathrm{C} 1, \mathrm{C} 2$ dan $\mathrm{C} 6$.

Beberapa saran yang ingin diajukan peneliti untuk penelitian mengenai Penggunaan model discovery learning, yaitu (1) Penggunaan model discovery learning pada hasil belajar ranah kognitif C3 sampai C5 memerlukan banyak latihan soal, sehingga tahapan pembelajaran aplikasi harus dioptimalkan. (2) power point dan vidio yang digunakan dalam materi menganalisis benda elastis dan pelastis perlu lebih mendalam lagi untuk meransang wawasan peserta didik.

\section{REFERENSI}

Gunawan, G., Sahidu, H., Harjono, A., \& Suranti, N. M. Y. The Effect of Project Based Learning with Virtual Media Assistance on Student's Creativity in Physics. Cakrawala Pendidikan, (2), 167-179. 
Gunawan, G., Harjono, A., Sahidu, H., \& Herayanti, L. (2017). Virtual Laboratory to Improve Students' Problem-Solving Skills on Electricity Concept. Jurnal Pendidikan IPA Indonesia, 6(2), 257-264.

Hayati, S.N., Hikmawati, \& Wahyudi. 2017. Pengaruh Model Pembelajaran Inquiri dengan Menggunakan Media Simulasi Terhadap Hasil Belajar Fisika Siswa Kelas X MIA SMAN 1 Lingsar Lombok Barat Tahun Pelajaran 2016/2017. Jurnal Pendidikan Fisika dan Teknologi. 3 (1): 48-54.

Herayanti, L., dan Habibi. 2015. Model Pembelajaran Berbasis Masalah Berbantuan Simulasi Komputer untuk Meningkatkan Keterampilan Berpikir Kritis Calon Guru Fisika. Jurnal Pendidikan Fisika dan Teknologi. 1 (1): 61-66.

Jauhari, T., Hikmawati. \& Wahyudi. 2016. Pengaruh Model Pembelajaran Berbasis Masalah Berbantuan Media Phet Terhadap Hasil Belajar Fisika Siswa Kelas X SMAN 1 Gunungsari Tahun Pelajaran 2015/2016. Jurnal Pendidikan Fisika dan Teknologi. 2 (1): 7-12.

Mubarok, C., \& Sulistyo, E. 2014. Penerapan Model Pembelajaran Discovery Learning Terhadap Hasil Belajar Siswa Kelas X Tav pada Standar Kompetensi Melakukan Instalasi Sound System di SMK Negeri 2 Surabaya. Jurnal Pendidikan Teknik Elektro. 3 (2) 215-221.

Muryani, A.D., \& Rochmawati. 2015. Perbedaan Hasil Belajar Siswa Menggunakan Model Pembelajaran Discovery Learning yang Berbantuan dan Tanpa Berbantuan Lembar Kerja Siswa. Jurnal Pendidikan Ekonomi . 1(1): 0-216.

Nurhayati, Fadilah, S., dan Mutmainnah. Penerapan Metode Demonstrasi Berbantu Media Animasi Software
PhET Terhadap Hasil Belajar Siswa dalam Materi Listrik Dinamis Kelas $X$ Madrasah Aliyah Negeri 1 Pontianak. Jurnal Pendidikan Fisika dan Aplikasinya (JPFA). 4 (2): 1-7.

Pebriyanti, D., Sahidu, H., \& Sutrio. 2015. Efektifitas Model Pembelajaran Perubahan Konseptual untuk Mengatasi Miskonsepsi Fisika pada Siswa. Jurnal Pendidikan Fisika dan Teknologi. 1 (2): 92.

Purwanto. 2013. Evaluasi Hasil Belajar. Yogyakarta: PUSTAKA PELAJAR

Sugiana, I.N., Harjono, A., Sahidu, H., \& Gunawan. 2016. Pengaruh Model Pembelajaran Generatif Berbantuan Media Laboratorium Virtual Terhadap Penguasaan Konsep Fisika Siswa pada Materi Momentum dan Impuls. Jurnal Pendidikan Fisika dan Teknologi. 2 (2): 61-65.

Sugiarti. 2015. Pembelajaran Fisika Berbantuan Simulasi Phet dalam Membangun Konsep Siswa. Wahana DIDAKTIKA, Jurnal Ilmu Kependidikan. 13 (1): 1-135.

Supradnyana, K.W., Garminah, N.N., dan Rati, N.W. 2016. Pengaruh Pembelajaran Discovery Learning Berbantuan Media Audio Visual Terhadap Hasil Belajar IPA Kelas IV. Jurnal Pgsd Universitas Pendidikan Ganesha. 4(1): 1-12. 